when by grow th they have become distressing through pressure, pain and the consequences arising upon vital, thoracic or abdominal organs. Or when there is such a constant peritoneal irritation as to produce pain or adhesions; or when by hemorrhage likely to be sacrificed. One case in which I removed the tumor in time to prevent another hemorrhage and which must have caused death if the operation had not been performed, recovered well in about thirty days.

Dr Muller says, "that while ovariotomy has been brought to a high degree of perfection, the operation of hysterectomy has not yet passed the first stages of its development." Not only bas the legitimacy of this operation been doubted and denied by experienced gynecologists, and while this question is being closely canvassed, the indications and contra-indications for a resort to it are gradually becoming settled. Nevertheless so much has been done, it is now claiming a place among the very grave surgical operations, which are not easily determined and may require a very careful exploratory incision and investigation before deciding that it shall be done and when it must be done in the careful judgment of the surgeon or surgeons, carefully weighing all the conditions; then they are not justly chargeable with temerity or cruelty in offering such relief, as only remains in this operation, with a percentage at best of mortality of one in five, or 20 per cent. This is the estimate of Thomas Keith, of London, and the adhesion of Sir Spencer Wells and Keith to Apostoli's methods of treatment, being among the world's most influential gynecologic surgeons, arrested the attention of all progressive and yet conscientious surgeons. While this is true, there are two factions of men, and all are not yet convinced of the efficacy of the galvanic treatment so ably defended by Apostoli, when he says that 95 per cent. of his cases were benefited, when not cured. I have written but suggestively, and here rest the subject for the present, hoping it may be like "a pebble cast into the ocean, its tiny wave may reach either shore" of professional opinion upon this subject.

\section{CRIMINAL ABORTION.}

\section{BY WILLIAM MCCOLLOM, M.D.} BROOKLYN, N. Y.

1 use the words in their legal sense, viz, the effecting of the unlawful expulsion of the contents of the womb at any time after conception before the term of gestation is complete. The very old English law made a distinction between the crime perpetrated before and after quickening. The rulings of the supreme court of severai of the American States corresponded with the old English law which was abolished a half century, more or less, ago. The Pennsylvania court was one of the first to discard the old doctrine and the courts of many of the other States have progressively fallen into line, and have ruled that it is a crime to destroy embryo life after gestation has begun. Judge Coulter, of Pennsylvania, ruled that "it is not the murder of a living child which constitutes the offence, but the destruction of yestation." An attempt by a physician or other person to procure an abortion is a crime, though the effort fail and the abortion is not produced, and it renders the party criminally guilty. When a physician prescribes medicine or gives advice and allows the patient or party to be lieve, or gives her reason for believing that it is given for the destruction of embryo life, though he does not intend such destruction, is little better than a criminal. I have heard physicians confess to such deception without seeming to realize that they were seriously compromising honesty and integrity and countenancing sin and crime.

Criminal abortion is frightfully prevalent and the practice is apparently on the increase among professed Christian women. It should be and it is the duty of the physician to enlighten applicants for relief from pregnancy who have no adequate idea of the criminality of the act. The women of the Church of Rome are betier instructed and made to keenly feel the great sin of murdering unborn human life. I might raise the question whether the clergy are doing their duty in the matter or not, but I am addressing medical men only. Let us do our duty, if our spiritual advisers neglect to do theirs, in denouncing this common crime and great sin. It is evident that women of the lower class have no adequate idea of the criminality of the act, for they unblushingly apply to the physician and to the druggist for medicine to abort pregnancy, or, in other words, to bring about the monthly sickness. Great ignorance of the criminality of the practice is manifested by edueated women, but it is not ignorance alone but a downright lack of moral sense as well, which greatly needs educating. The common law at the present day does not make the destruction of an unborn child murder. I quote Blackstone on English law: "Though to kill the fetus in utero is as such by common law no murder, yet if it be born alive and die sub. sequently to birth from wounds received in the womb, or from the means used to expel it, the offence becomes murder in those who cause or employ them." I also quote from another distinguished jurist, Wharton, "Law of Homicide," 93: "If a person intending to procure an abortion, does an act which causes the child to be born earlier than its natural time, and therefore in a state much less capable of living and it afterward die in consequence of such premature exposure, the person who by this misconduct brings the child into the world, and puts it into a situation in which it can not live, is guilty of murder, though no direct injury to the ehild is proved; and the mere existence of a possibility that something might have been done to prevent death, does not lessen the crime." We are inclined to the belief that such law is not good common sense; to kill the child in utero according to Blackstone is not murder or infanticide, but to inflict such injury upon it that though it is boru alive and dies in consequence of the injury it is murder.

Some years ago I attended a woman, the wife of an attorney-at-law, seven monthe or more advanced in pregnancy, the child stillborn; the brain had been punctured through the eye from some instrument; this was not technically murder under common law, but I bluntly charged the mother with murder in the presence of her husband and friends, pointing out the evidence of it, and there was no denial. I have repeatedly been shocked at the manifest lack of moral sense in intelligent women in applying for medicine to reëstablish the menstrual function when it was evident that they believed the absence of the menses. due to pregnancy. The woman sometimes attempta. to justify the act because she does not positively know that conception has taken place. The physi- 
cian's excuse for giving noxious drugs or for sounding the womb when miscarriage results that he did not know that the suppression was due to pregnancy renders him not less criminally liable.

Under the older English law for an attempt to procure a criminal abortion without proof of the woman's pregnancy conviction could not take place. More recent rulings as well as amended laws now make the attempt to procure a miscarriage a crime. It has been the law of France for more than fifty years, that the proof of pregnancy is not essential to the commission of the crime. We try to excuse Christian women for asking us to terminate preg. nancy on the ground of ignorance of the law of man, if not of the law of God. If they took as much pains to become enlightened in the common law regarding it as they do to how it can be accomplished with or without aid from others they would not long remain in ignorance in the matter. Physicians long in general practice know that the practice of criminal abortion is common; and that it is not confined to the laity or to the quack and the pretender. Sometimes the ordinary physician who may be a member of a regular medical society violates his duty; and the distinguished college professor without the fear of God or of sufficient fear of human law takes his large fee for the criminal act. I am not drawing on the imagination, but state what I know to be true. Such statement does not sound well, but this fearful immoral destructive practice can not be checked unless facts are stated and proclamation is made of this great evil.

I have no belief that the practice is common among physicians who have a reputable standing with the profession in the neighburhoods where they are known. The moral status of physicians is high and I trust that we have no more black sheep than the other learned professions. As we go down the scale from the higher to the lower the evil grows greater, until the criminal abortionist, who may be a graduate of a regular medical college, loses all shame and not only sends out his advertisements to the laity, but his cards at frequent intervals to reputable physicians as well. These villains would not continue to inform the medical profession at considerable expense to themselves year after year unless their business was helped by it. A little lower down in intelligence, if not in wickedness, comes the so-called midwife and the woman who prefixes doctor to her name, and poses as a dermatologist or specialist in disease of females; they flourish in many localities.

Now we come to the economical woman and her economical friend, with their skewers, steel knitting needles and other instruments of murder. Quite recently an intelligent, educated profeseed Christian woman whom I attended in a miscarriage in the fourth month of pregnancy, confessed without expression of sorrow or remorse that she had effected the abortion with her own hand by pushing a knitting needle into the womb, following the instruction of another young woman who had repeatedly succeeded in destroying embryo life in her own person and was kindly instructing her young friends in the art without hope of pecuniary reward. It is only necessary for me to briefly call attention to the existing criminal facts, for all physicians who have had full opportunity to observe know that the alleged statements are true, and not overdawn; true of the city and true of the country.
Much might be said of the far-reaching, demoralizing destructive influence upon woman, upon the community, upon the State, upon the world; but the portraiture of the facts, bad as they would appear, I fear would have little influence in arresting the practice. The moral sense in woman, and possibly in the medical profession as well, has degenerated as regards this inatter. The physician is so related to woman in his professional duties that he can do much, if he will, to instruct her as to the law and to show her that she would be a criminal, and shock her into a sense of her duty. It is presumed that. few people know that the penal code of many of the States make the woman guilty of manslaughter if she consents to the procuring of a miscarriage. I quote from section 194. New York penal code: "A woman quick with child, who takes, or uses, or submits to the use of any drug, medicine or substance, or any instrument or other means, with intent to procure her own miscarriage, unless the same is necessary to preserve her own life or that of the child whereof she is pregnant, if the death of such child is thereby produced, is guilty of manslaughter in the second degree."

When one woman advises another woman to procure an abortion, instructs her as to the method or assists her in any way in its performance, she becomes a criminal and is guilty of manslaughter.

Section 191, Penal Code of New York, says: "A person who provides, supplies or administers to a woman, whether pregnant or not, or who prescribes for or advises or procures a woman to take any medicine, drug or substance, or who uses or employs, or causes to be used or employed, any instrument or other means, with intent to procure the miscarriage of a woman, unless the same is necessary to preserv $\theta$ her life, in case of the death of the woman or of any quick child of which she is pregnant is thereby produced, is guilty of manslaughter in the first degree."

The field for missionary work is a large one and should be faithfully worked, both by the conscientious physician as well as by the Protestant Christian clergy, who perhaps fully understand the enormity of the sin if they do not know how prevalent it is. It is not a pleasant subject to discuss before a mixed audience. Young women could be reached, inetructed and warned by a properly published circular or tract sent to them by Christian organizations at intervals, where personal instruction would not be practicable. There is little to criticise, as it relates to the laws of most of the older and some of the newer States of America. A recent ruling, June, 1895, by the supreme court of Kansas, rendering an important section of the Crimes Act as it relates to criminal abortion invalid, is a long step of about fifty years backward. The law provides that an attempt on the part of any one to abort "any woman pregnant with a quick child" "shall be guilty of manslaughter in the second degree;" this is declared inoperative and invalid "where neither the death of the child nor the mother results from the acts committed." The low moral sense of the community, as it relates to the offence, has much to do in the non-enforcement of the law. The criminal is seldom put under arrest unless the woman is murdered, and then the party, if convicted, frequently gets the minimum penalty prescribed by law. If physicians would do their duty and make complaint in all cases when it comes to their knowledge that physicians or other persons are violating 
the law in the destruction of unborn human life, it would do much to lessen the practice. I have more than once made written appeal accompanied with a threat that unless I could be satisfied that the practice would stop, I would euter formal conplaint to the legal authorities. Parties have responded, pleaded for mercy and given solemn promise never to again produce the miscarriage of a pregnant woman for any reason until they had held a consultation with a reputable physician, and its necessity was advised. It is not safe or best that any doctor procure the miscarriage of a woman in case of necessity until a consultation with another physician is had; such practice would protect himself against suspicion of wrong-doing, and materially help to trace and convict the criminal. So long as it is allowed the physi. cian to produce the miscarriage or the abortion of woman without consultation the evil will not be materially checked, for the criminal abortionist is a perjurer and when under trial in court will swear if necessary to avoid conviction, that the act was performed to prevent the death of the woman from disease, pelvic deformity, or for some reason given, satisfactory to the jury. It is very easy to speak upon this shocking criminality practiced by professed Protestant Christian men and women, as well as by the ungodly, and to moralize upon the destructive influence, especially upon woman, but it is difficult to solve the question when we ask, What is the remedy? How can it be checked?

\section{CASES ILLUSTRATIVE OF DIFFERENT FORMS OF COLOR-BLINDNESS.}

CASE I.-CONGENITAL COLOR-BLINDNESS. CASE II, - TOBACCO COLOR-BLINDNESS.

CASE III.--TRAUMATIC COLOR-BLINDNESS.

A Clinical Jecture delivered before the Senior Class at the Jefierson Medical College, Philadelphia, April 5, 1895.

BY WILLIAM THOMSON, M.D.

PROFESSOR OF OPHTHALMOLOGY IN THE JEFFERSON MEDICAL COLLEGE; OPHTHALMIC SURGEON TO TEE PEN NSYLVANIA RAILROAD, ETC. [Reported stenographically for the Journal.]

Gentlemen:-Your Clinical Professor of Ophthalmology has invited me to address you on the subject of color-blindness. I must suppose that you have been made acquainted with the anatomy and physiology of the eye, by the teaching of my friend and colleague, Professor Hansell, who is so well qualified to instruct you upon this subject. Taking, therefore, your familiarity with these preliminary matters for granted, I will proceed at once to tell you what is meant by color blinduess; and how the condition may be recognized. I will also explain the tests, and give you clinical illustration of their application. In this way, you will get a practical demonstration of the methods of examining patients who are suspected of having a defective color sense.

When we speak of congenital color-blindness, we mean that the eye may be perfectly normal in its structure, have no anomaly of refraction, and be a perfect optical instrument, except for one defect, and that is the inability to distinguish the difference between colors, which to ordinary, normal eyes is very obvious, such as red and green. It is precisely these colors, however, which have been selected for signals on the railroads and on shipboard, where failure to recognize them may cause serious loss of life and property. You will appreciate this better when I tell you that there are cases of total color- blindness in which the solar spectrum looks to the patient like a lead-pencil drawing of it; where, from red to indigo, the spectrum looks as if drawn in different shades of gray. Such cases, however, of total color-blindness are rare; indeed, I have never met with a case of this kind. On the other hand, cases of partial color blindness are common. For instance, there is blue, yellow, red, and green blindness. What is most commonly meant, at the present day, by color blindness, on occount of its wide-spread and far-reaching consequences, is the inability to distinguish between red and green, or green and gray. When you realize that the individual presenting this defect to the examiner would show the same in ability to distinguish between red and green flags or lights, which are commonly used as signals at sea or on railroads, you will understand the great importance of testing the eyes of all pilots, and of engineers and brakemen particularly. The correct interpretation of those signals depends upon the ability of the engineer or lookout to recognize certain colors at sight. The white light or flag on the railroad means: "Go ahead;" the green, "Proceed with caution;" the blue, "Do not move it " but the red light or flag means imperatively, "Halt." It is important to recognize lights at sea, for another reason, because by their aid the course is indicated in which a ship is sailing. The red light is hung at the port and the green at starboard, with a white light on the masthead. By the relative positions of these lights the direction may be known. In the recent calamity by which the steamship Elbe was injured in a collision in the North Sea and foundered with all on board, I am not sure that it was not due to the defect in vision of which I speak to-day. The accident occurred at night when there was no storm, and the atmosphere was clear enough for ships to see each other for a long distance before they met. It might have been due to the fact that the lookout on the Craithie could not tell which way the Elbe was going, owing to color-blindness, which prevented him from correctly interpreting the signals on the Elbe. So, you see that this is a matter of very great importance, especially to all of us who may have occasion to travel by land or water.

Now, we will see if we can approach this subject in some way so that you will get a clear idea of the color sense and of the relations of colors. Here, on this plate I show you a colored representation of what is commonly known as a "spectrum" "or solar spectrum." This teaches you that if you go into a dark room and make a small hole in a shutter, that the beam of light (or if passed through a prism) will break up into this arrangement of colors upon a screen, with blue light at one end and red light at the other, as everybody knows. The reason why the spectrum is formed is because a beam of whitelight is made up of a number of rays having different wave lengths, or rates of vibrations. Thus, the red rays at one end of the spectrum have about four hundred million millions of vibrations per second, while the violet at the other end have over seven hundred and fifty million millions. All rays under four hundred billions of vibrations per second are not perceptible as light and are known as heat rays, while those higher than the violet can not be appreciated by the human eye and are only recognized by their chemic and physical effects. Between these extremes of red and violet are found the orange, yellow, green and blue rays with 